\title{
DISKRIMINASI PENDIDIKAN DI INDONESIA: ANALISIS TEORI DEMOKRASI PENDIDIKAN ISLAMI
}

\author{
Astrid Veranita Indah \\ UIN Alauddin Makassar
}

\begin{abstract}
Education is the formation of human character that leads to individual independence. An individual is able to develop the potential of self-reliance and quality of resources through the democratization of education. Democratizing education requires an adequate teaching and learning tool, but in a pandemic condition a conducive learning atmosphere is impossible to achieve. Education will undergo significant changes when faced with a new situation that is different from the constant rhythm of life of Indonesian society.
\end{abstract}

This study is a qualitative research literature. The researchers will choose between primary sources and secondary sources; classifying the data; then presenting the data. While the method of analysis using the method of philosophical hermeneutics, which starts with a description, interpretation, historical continuity, and heuristics.

Democracy of education creates the creativity of students in increasing intellectual, spiritual intelligence, and developing skills in themselves that are in accordance with the conditions of social society. The aim of democratization education is to provide equal rights for each individual to develop their potential and gain knowledge. Intellectual development is based on empathy, sympathy, and creativity. With the democracy of education, every individual has equal rights in acquiring knowledge in the midst of a pandemic Covid-19. Democracy of education also avoid someone has the mindset to control and dominate the other.

Keywords: Education, Pandemic Covid-19, Democracy

\section{PENDAHULUAN}

Hold the Basic Equality of All Human adalah salah satu nilai dasar dalam membangun demokrasi pendidikan. Tujuan demokrasi pendidikan adalah menghasilkan manusia bebas, kreatif, dan setara pada setiap individu. Perlakuan sama juga harus dinikmati oleh para peserta didik baik di kota maupun di daerah, baik dari kelas menengah-atas maupun kelas bawah. Persamaan dan kesetaraan bagi seluruh umat manusia dalam pendidikan mengalami degradasi sejak pendidikan di Indonesia memberlakukan sistem online pada setiap proses pengajaran.

Sistem online atau belajar dalam jaringan memerlukan kesiapan dan ketersediaan teknologi yang memadahi, sumber daya manusia yang akuntable, dan kecukupan keuangan sebagai penunjang perangkat sistem informasi. Ketersediaan pada ketiga hal di atas akan mendukung sistem pembelajaran online. Realitas yang terjadi di masyarakat, sistem online justru hanya dinikmati oleh masyarakat kelas menengah-atas. Sementara 
masyarakat kelas bawah semakin terdiskriminasi dalam memperoleh akses jaringan sistem informasi dan ketidakmampuan sumber daya manusia. Persamaan hak dan kesetaraan bagi seluruh umat manusia sedang dihadang sebuah persoalan bencana pandemi pada Era Kontemporer.

Persamaan hak dalam pendidikan merupakan salah satu upaya membangun kesetaraan antara masyarakat kelas sosial bawah, menengah, dan kelas atas. Persamaan hak dalam memperoleh pendidikan terwujud melalui akses pengetahuan, penggunaan teknologi, dan penerimaan umpan balik dari pendidik kepada peserta didik. Persamaan hak dalam memperoleh pendidikan sangat sulit terwujud terutama kepada masyarakat kelas sosial ke bawah. Dalam sebuah kasus, seorang pendidik di daerah terpencil harus berjalan jauh agar peserta didik menerima pendidikan, dalam kondisi pandemi Covid-19. Realitas sosial masyarakat kelas atas justru memperoleh kemudahan dalam memperoleh pendidikan dalam kondisi pandemi Covid-19. Akses penggunaan teknologi dalam jaringan malah mempermudah proses belajar-mengajar dalam masyarakat perkotaan, terutama bagi masyarakat kelas atas. Para peserta didik dengan mudahnya mengakses pengetahuan meskipun harus tinggal di rumah. Sementara para peserta didik dari masyarakat kelas sosial bawah, sangat kesulitan mengakses pengetahuan, terkendala minimnya jaringan dan kuota internet. Demokrasi pendidikan sedang diuji dalam kondisi wabah Covid-19 menuju kehidupan new normal di Era Kontemporer.

Indonesia merupakan salah satu negara yang terkena dampak pandemi Covid-19. Pendidikan dan pengajaran di Indonesia mulai bergeser dari pengajaran tatap muka di kelas menjadi pengajaran secara daring. Ketersedian jaringan komunikasi menjadi satusatunya alat memperlancar sistem pendidikan dan pengajaran secara daring. Kemendikbud (2020) bahkan memberikan kebijakan dalam mengatasi akses jaringan internet di pedalaman. Salah satu cara untuk mengatasi keterbatasan sarana pembelajaran adalah gagasan Kemendikbud melalui Program Belajar dari Rumah (BDR) yang ditayangkan di TVRI. Acara ini merupakan salah satu alternatif belajar yang diberikan Kemendikbud untuk membantu banyak keluarga yang memiliki keterbatasan pada akses internet sehingga anak-anak memperoleh stimulus untuk terus belajar di rumahnya masing-masing.

Persoalan akses pendidikan tidak berhenti sampai disini, anak-anak yang tinggal di daerah pelosok mengalami keterbatasan listrik, tidak mampu mengakses siaran program belajar dari rumah di TVRI setiap hari. Pemanfaatan jaringan radio manjadi salah satu upaya mengatasi persoalan keterbatasan jaringan di daerah pedalaman. Menurut Titis Kartikawati dalam Tim Komunikasi GT Nasional (2020) dalam telekonferensi bersama para guru dan pegiat pendidikan yang disiarkan melalui Media Center Gugus Tugas Percepatan Penanganan COVID-19 di Graha Badan Nasional Penanggulangan Bencana (BNPB) Jakarta, Sabtu (2/5) mengatakan bahwa tidak semua daerah mempunyai jaringan internet, sehingga pihak sekolah berkolaborasi dengan RRI setempat, mengadakan program belajar satu jam dengan bantuan para pendidik. 
Persoalan keterbatasan jaringan internet dan keterbatasan jaringan listrik mampu dijangkau dengan upaya pemerintah mengadakan Program Belajar dari Rumah yang ditayangkan di TVRI dan Program Belajar Satu Jam kolaborasi dengan RRI. Namun penerimaan pengetahuan dari pendidik kepada peserta didik ataupun sebaliknya belum maksimal. Masyarakat di daerah pedalaman hanya menerima pengetahuan dari pendidik, sementara masyarakat di perkotaan bisa dengan leluasa berdiskusi, berdialog dengan para pendidik melalui akses jaringan internet yang memadahi. Akibatnya adalah pendidikan di masa pandemi Covid-19 belum mencapai taraf demokratisasi pendidikan. Diskriminasi ekonomi dan sosial antara kelas bawah dengan kelas menengah-atas menjadi persoalan utama dalam menerapkan demokratisasi pendidikan. Masyarakat di pedalaman hanya menempatkan anak pada posisi pasif, seperti yang diterapkan oleh pendidikan tradisional. Sementara pendidikan progresif belum menjangkau masyarakat dari kalangan bawah. Demokrasi pendidikan di Indonesia menghadapi beragam persoalan, bukan hanya tentang ketersedian akses namun juga kesiapan negara menyediakan sarana-prasarana dan menjamin kesamaan hak bagi setiap Indonesia. Tulisan ini akan membahas bagaimana pandangan para tokoh liberlisme tentang demokrasi pendidikan? Apa demokrasi pendidikan islam, terutama ketika jaman nabi Muhammad SAW? Tujuan yang dicapai dalam tulisan ini adalah memberikan penjelasan dan pemahaman tentang demokrasi pendidikan dalam memberikan solusi terhadap diskriminasi pendidikan di Indonesia.

\section{METODE PENELITIAN}

Metode penelitian ini adalah metode hermeneutika filosofis, dimulai dari deskripsi; interpretasi terhadap karya-karya pemikiran para filsuf pendidikan; kesinambungan historis yaitu dengan memberikan pemahaman menyeluruh tentang demokrasi pendidikan dalam sejarah pekembangan pemikiran filsafat; dan heuristik yaitu memberikan pemahaman baru tentang wacana demokrasi pendidikan Islam serta dapat mengimplementasi dalam persoalan diskriminasi pendidikan di Indonesia.

\section{KAJIAN TEORI}

Kata demokrasi secara etimologi berasal dari Yunani, yaitu demos (rakyat) dan kratein (memerintah). Demokrasi (pemerintahan oleh rakyat) dalam pemikiran Yunani berarti rakyat menjalankan seluruh kekuasaan politik, sekaligus menentang pemerintahan monarki, aristokrasi, tirani, atau oligarki (Bagus, 2000. 154). Demokrasi lahir sebagai upaya mengatasi konflik dengan konsesus. Dalam kehidupan berdemokrasi, konflik dapat diselesaikan dengan konsesus. Dalam hal ini, konsesus mensyaratkan adanya kesetaraan hak pada setiap individu, dan adanya loyalitas individu kepada sistem politik.

Konflik juga terjadi dalam dunia pendidikan, lalu melahirkan demokratisasi pendidikan. Pertama sebuah demokrasi pendidikan hadir sebagai upaya perlawanan terhadap sistem pendidikan tradisional. Dalam sistem pendidikan tradisional, transfer pengetahuan berlangsung searah. Guru memiliki otoritas pengetahuan sebagai sumber 
kebenaran dalam pendidikan. Murid adalah kertas putih kosong yang siap diberikan pengetahuan oleh otoritas pengetahuan.

Kedua, demokrasi pendidikan muncul untuk melawan suatu kelompok yang menyokong kapitalisme dan mengembangkan modal untuk mendominasi dan menguasai orang lain. Dalam kehidupan manusia di Era Kontemporer, muncul kalangan-kalangan elite dari latar belakang pengusaha dan pemodal yang berusaha mendominasi kebijakankebijakan politik. Menurut Tampio (2006. 75) bahwa pendidikan progresif dalam pemikiran Dewey, mengajarkan anak-anak mengejar kepentingan dan suara mereka sendiri. Pada Abad ke-20, kaum muda berpartisipasi dalam gerakan melawan Perang Vietnam, mendirikan Greenpeace, dan mendirikan komunitas berbasis organik. Pendidikan mendorong kaum muda berjuang mendapatkan kebebasan dan sarana mengekspresikan dirinya sendiri. Gerakan reformasi pendidikan adalah gerakan membangun semangat melawan elit politik dan ekonomi.

Ketiga, demokrasi pendidikan menentang segala bentuk sikap individualis ekstrim dalam kompetisi pendidikan tidak seimbang. Pendidikan Era Kontemporer lebih mengutamakan nilai-nilai individualistik daripada rasa solidaritas terhadap sesama manusia. Akibatnya adalah muncul kesenjangan sosial dan krisis kemanusiaan di Era Kontemporer. Bagi Tampio (2006. 80), filsafat pendidikan dalam pemikiran Dewey bertujuan mendisribusikan kepentingan secara luas untuk memecahkan persoalan kesenjangan ras dan suku. Setiap anak mendapatkan pendidikan yang sama berdasarkan permintaan mereka sendiri. Hal tersebut mendorong seseorang mempertanyakan adanya kesetaraan antara hak dan kewajiban bagi pekerja kepada pemilik sarana produksi. Pendidikan yang setara bagi setiap umat manusia, bertujuan membuka kesadaran kritis manusia terhadap dominasi suatu kelompok tertentu.

Demokrasi pendidikan digagas oleh beberapa filsuf Liberalisme, yaitu: John Dewey, Bertrand Russell, dan Noam Chomsky. Secara eksplisit kecenderungan Liberalisme awal mengarah pada demokrasi yang dikuatkan dengan hak-hak kepemilikan. Semua manusia dilahirkan sama, ketidakadilan mengikutinya merupakan suatu produk lingkungan. Kepercayaan ini kemudian mendorong penekanan luar biasa pada nilai penting pendidikan yang bertentangan dengan prinsip bawaan sejak lahir (Russell, 2016. 783). Menurut Russell (2016.1066-1077), John Dewey adalah pemikir Liberalisme awal yang lahir tahun 1859, diakui secara umum sebagai filsuf terkemuka di Amerika Serikat. Ketika Dewey menjadi professor di Chicago pada tahun 1894, Dewey mendirikan aliran progresif dan menulis tentang pendidikan. The School and Society (1899) merupakan kumpulan tulisan tentang pendidikan pada masa itu.

John Dewey secara konsisten memikirkan demokrasi pendidikan. Kesetaraan dan kreativitas adalah kunci utama dalam membangun demokrasi pendidikan. Hal ini kemudian memengaruhi pemikiran pendidikan Chomsky. Noam Chomsky lahir tahun 1928 yang dikenal sebagai filsuf Amerika keturunan Yahudi. Chomsky saat ini adalah seorang professor linguistik di Massachusetts Institute of Technology (MIT), Amerika 
Serikat. Chomsky adalah salah satu intelektual, filsuf, dan politis yang sering melontarkan kritikan tajam terhadap kebijakan Amerika Serikat. Salah satu karya Chomsky berkaitan dengan pendidikan ada dalam Chomsky on Education and Democracy.

\section{HASIL PENELITIAN DAN PEMBAHASAN}

Globalisasi telah mengubah berbagai sendi kehidupan manusia. Pertama, globalisasi menempatkan manusia menjadi budak dari ideologi kapitalisme. Manusia saat ini adalah manusia dengan gaya hidup konsumerisme. Kehidupan manusia ditentukan oleh konsumsi barang-barang yang sebenarnya hanya sebagai penanda identitas diri. Konsumerisme mengakibatkan masyakat memandang pendidikan hanya sebagai alat mengumpulkan kekayaan dan membelanjakan untuk konsumsi barang-barang. Akibatnya adalah kebebasan manusia ditentukan oleh pemilik modal melalui bentukan gaya hidup ideal. Pendidikan saat ini bertujuan membentuk manusia dengan berbagai keterampilan yang siap bekerja demi mengumpulkan kekayaan. Pendidikan ideal adalah pendidikan yang mampu mencetak manusia pekerja pada sebuah perusahaan besar. Bagi Azyumardi Azhra (2009. 66) bahwa modernisasi di Negara Barat terjadi proses sekularisasi dan penyingkiran agama ke dalam kehidupan publik. Modernisasi di Indonesia menghasilkan gairah atau antusiasme baru dalam meningkatkan kesetiaan kepada agama. Kaitan antara kondisi ekonomi masyarakat dengan pengamalan ajaran agama sangat terlihat jelas di Indonesia. Dengan kian baiknya ekonomi masyarakat, maka semakin baik pula masyarakat menunaikan ibadah.

Kedua, globalisasi menyebabkan kesenjangan sosial antara kelas menengah ke atas dengan kelas bawah semakin dalam. Kesenjangan sosial terlihat pada ketersediaan akses antara masyarakat perkotaan dengan masyarakat pedesaan. Anak yang cerdas dan pintar berasal dari kelas sosial menengah-atas dan memiliki akses pendidikan yang memadahi. Sementara seorang anak yang kurang pintar berasal dari kelas bawah dengan keterbatasan akses pendidikan. Di Indonesia pada saat pandemi Covid-19, pemerintah diam, tidak mampu mengambil kebijakan di tengah masyarakat pro demokrasi dan pro kapitalisme. Akibatnya adalah terjadi kesenjangan sosial antara masyarakat kelas bawah dengan masyarakat kelas menengah-atas. Masyarakat bawah tidak memperoleh pendidikan selayaknya masyarakat menengah-atas. Karunia (2020) menuliskan bahwa berdasarkan data Kemenaker per 20 April 2020, terdapat 2.084.593 pekerja dari 116.370 perusahaan dirumahkan dan kena PHK akibat terimbas pandemi corona ini. Adapun rinciannya, sektor formal 1.304.777 pekerja dirumahkan dari 43.690 perusahaan. Sementara yang terkena PHK mencapai 241.431 orang dari 41.236 perusahaan. PHK berdampak pada usaha para orangtua untuk menyediakan pendidikan optimal bagi anak-anak. Akibatnya adalah para siswa dari orangtua yang terdampak PHK, kesulitan melaksanakan pembelajaran daring. Kesenjangan sosial di masyarakat semakin dalam ketika masa pandemi Covid-19 di Indonesia. Sementara pemerintah tidak mampu berbuat banyak untuk membantu perkenomian dan pemerataan. 
Ketidakmerataan dan diskriminasi ekonomi dan sosial berdampak pada penerimaan akses pendidikan masyarakat Indonesia. Masyarakat kelas menengah-atas dengan mudahnya menerima pendidikan dalam kondisi pandemi, sementara kelas bawah atau masyarakat miskin terkendala mengikuti pendidikan dengan akses jaringan internet dan teknologi kurang memadahi.

John Dewey seorang liberalisme-klasik Amerika, fokus mengkaji pendidikan pada student centered. Fokus utama pendidikan dalam pemikiran Dewey adalah mengembangkan potensi pengetahuan, kreativitas, dan keaktifan peserta didik. Student centered menolak pendidikan tradisional. Dalam pendidikan tradisional, peserta didik adalah kertas kosong, yang siap diisi pengetahuan. Dewey kemudian menawarkan dua metode pendidikan untuk mengkritisi pendidikan tradisional.

Pertama, Dewey (1938. 73-74) menawarkan sebuah metode pendidikan, learning with experience. Learning with experience merupakan langkah awal dalam mengembangkan pengalaman secara progresif. Langkah selanjutnya adalah pengalaman tersebut secara mendalam dan bertahab dikembangkan oleh orang-orang ahli dan berpengalaman, untuk mengatasi berbagai persoalan pendidikan. Tujuan pendidikan dari pemikiran Dewey adalah mencetak para peserta didik setelah lulus menjadi orang-orang yang mampu memberikan solusi atas persoalan pendidikan. Kurikulum dibuat untuk kebutuhan para peserta didik di masa depan, sehingga guru menyesuaikan kebutuhan para peserta didik. Sejalan dengan gagasan pragmatisme, Dewey menekan bahwa pembelajaran adalah yang sesuai dan berguna bagi peserta didik setelah lulus.

Kedua, menurut Propkin (1980. 270) bahwa Dewey mengajukan sistem pendidikan untuk mengembangkan metode-metode problem solving. Peserta didik mempelajari bagaimana menyelesaikan masalah dan mengubah dunia dengan perplexities and evernew problem. Pendidikan seperti ini akan membentuk seseorang untuk hidup dalam sebuah masyarakat demokratis, dan mempertahankan perkembangan organisasi sosialpolitik. Tujuan pendidikan bagi Dewey, bukan menghasilkan barang-barang bagus yang bisa dijual dan menambah kas negara, melainkan menghasilkan manusia-manusia bebas (produces free men) yang mampu berhubungan satu sama lain dalam situasi yang setara (equal relation). Kesetaraan bagi setiap individu bukan hanya pada tataran pendidikan, namun juga perjuangan dalam bidang ekonomi-politik.

Menurut Chomsky (2003. 31), Dewey dan Russell memperjuangkan, mengorganisasikan, dan memprotes pekerja baik laki-laki maupun perempuan sejak awal abad ke-19. Dewey dan Russell memperjuangkan kebebasan, keadilan, dan menahan para penyokong kapitalisme yang didukung negara, untuk memperpanjang kekuasaannya. Demokrasi dan kapitalisme tidak selalu berjalan selaras, bahkan terkadang meniadakan satu sama lain. Thommas Jefresson membedakan antara kaum Aristokrasi dengan kaum Demokrat. Kaum Aristokrasi saat ini adalah kaum penyokong kapitalisme, sementara kaum Demokrat adalah kaum pejuang hak asasi manusia. Baik Adam Smith maupun Thommas Jefresson telah memperingatkan bahaya dari kaum Aristrokrasi atau struktur 
pemilik modal yang ingin memperoleh kekayaan dan menguasai manusia yang lain. Chomsky bahkan menawarkan sebuah paradigma baru dalam sistem pendidikan di tengah dominasi kapitalisme. Pendidikan menurut Chomsky adalah:

"Education is, of course, in part a matter of schools and colleges and the formal information systems, that's true ehether the goal of education for freedom and democracy, as dewey advocates, or education for obedience and subordination and marginalization, as the dominant institutions require." (Chomsky, 2003: 36).

Pendidikan bukan hanya tentang dominasi dan kompetisi antar sesama manusia. Pendidikan juga bukan untuk menunjukkan individualitas manusia dan memperlebar kesenjangan sosial. Pendidikan adalah menghasilkan manusia bebas, kreatif, dan simpatik dalam keadaan setara. Sebagai seorang ahli linguistik, Chomsky menekankan pentingnya anak-anak memahami bahasa. Sebagai seorang kritikus politik, bahwa pendidikan penting untuk membangun generasi muda yang bertanggung jawab dalam berpolitik.

Chomsky (2002. 163) memandang perlunya menerapkan paradigma pendidikan humanistik, dari pemikiran Russell. Analogi dari konsep humanisme dalam pendidikan adalah seorang anak sebagai seorang tukang kebun yang menghormati pohon muda, memiliki sifat intrinsik, akan berkembang menjadi bentuk mengagumkan, dengan memberi pupuk, air, dan cahaya secara tepat. Dalam pendidikan humanistik, seorang anak memliki sifat bawaan mampu membawa pada kreativitas. Tujuan pendidikan adalah mengekplorasi imaginasi dan kreativitas sehingga mampu memperkaya kehidupan seorang anak dengan cara yang unik. Manusia yang berpikir bebas akan menciptakan kreativitas dan inovatif. Menurut Jackson (1998. 66) pendidikan seperti Laboratory School yang dibangun oleh John Dewey menempatkan pendekatan keahlian praktis, seperti memasak, berkebun, menyapu, dan bertukang. Tujuan dari sekolah eksperimen adalah adanya hubungan antara kehidupan di luar sekolah dengan aktivitas sehari-hari.

\section{Pendidikan Humanisitik}

Akses pendidikan yang tidak merata mengakibatkan kesenjangan sosial dalam menerima pengetahuan, akibatnya adalah pendidikan hanya didominasi oleh orang-orang pemilik modal. Sikap rakus individu dan tidak ada solidaritas antar sesama mengakibatkan kompetisi tidak seimbang dalam ranah pendidikan. Pemerintah dalam hal ini terkadang berdiam diri, bahkan justru melanggengkan nilai-nilai individualistik. Pendidikan saat ini sebagaimana pandangan Chomsky dan Smith adalah menuntun manusia untuk menguasai manusia yang lain, dengan perbedaan akses pengetahuan. Pendidikan saat ini adalah pendidikan yang fokus terhadap prestasi dan mengumpulkan kekayaan bagi diri sendiri.

Demokrasi pendidikan Islam mencela sikap orang-orang yang tidak mengantarkan sesama manusia kepada Allah SWT, dan orang-orang yang justru memperbesar kesombongan diri mereka. Sebagaimana dalam Ali Imran (79): 


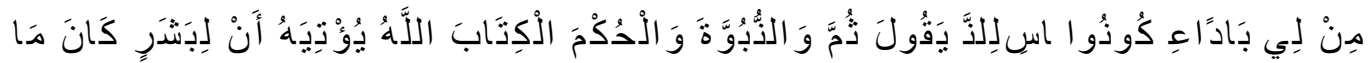

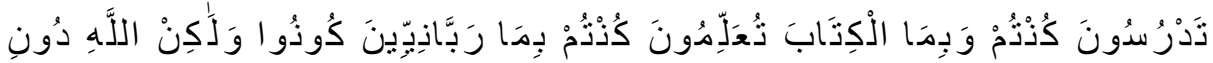

Tidak wajar bagi seseorang manusia yang Allah berikan kepadanya Al Kitab, hikmah dan kenabian, lalu dia berkata kepada manusia: "Hendaklah kamu menjadi penyembah-penyembahku bukan penyembah Allah". Akan tetapi (dia berkata): "Hendaklah kamu menjadi orang-orang rabbani, karena kamu selalu mengajarkan Al Kitab dan disebabkan kamu tetap mempelajarinya.

Ayat tersebut adalah ketika seseorang yang sudah diberikan kenabian, kemudian mereka sombong sehingga menyuruh orang-orang menyembah selain Allah SWT. Orangorang yang diberikan kitab, Allah menyebut mereka sebagai Rabbani. Rabbani menurut al-Qurtubi, memiliki akar kata yang sama dengan Rabb, dan disandarkan kepada Rabb itu. Secara terminologi, Rabbani adalah pendidik yang mendidik orang-orang pada saat masih sedikit pengetahuannya. Dari saat tidak mengetahui apa-apa sampai mereka mancapai fase kematangan. Seolah-olah Rabbani mengikuti sifat Allah SWT, dalam mempermudah urusan (pendidikan). Dalam ayat tersebut, Rabbani adalah orang-orang yang diberikan kemampuan pengetahuan yang luas, namun harus menjadi pendidik yang lemah lembut, santun, sebagaimana pola pendidikan yang diajarkan oleh Rasulullah SAW.

Ramayulis (2011. 43) bahwa Rasulullah SAW dalam memberikan pengajaran kepada umat berpedoman pada al-Qur'an dan Hadist, telah terdapat dasar-dasar pengembangan ekonomi berbasis Islam. Dalam al-Qur'an diwajibkan mengeluarkan zakat (zakat fitrah dan zakat harta). Untuk melindungi harta milik perseorangan, keluarga, atau bersama, maka Nabi Muhammad SAW melarang pencurian dalam segala bentuknya. Peraturan tersebut menunjukkan bahwa agar harta kekayaan dapat dipergunakan sebaikbaiknya, dan tidak merugikan orang lain. Harta kekayaan juga harus dipergunakan semaksimal mungkin untuk kesejahteraan bersama. Berdasarkan pemaparan tersebut, harta kekayaan yang dapat dipergunakan dengan maksimal untuk membantu sesama manusia, maka akan memperoleh kesetaraan ekonomi dan sosial masyarakat Indonesia. Memaksimalkan mengeluarkan zakat dan menghindari segala larangan riba serta menumpuk harta kekayaan akan membentuk pribadi toleran terhadap sesama manusia.

\section{Meningkatkan SDM: Kesimbangan Iman, Ilmu, dan Akal}

Pendidikan dengan tujuan memanusiakan manusia merupakan salah satu pendidikan berdasarkan pada sikap empati, solidaritas, dan kesetaraan bagi setiap manusia. Kesetaraan bagi setiap manusia dalam pendidikan adalah melalui peningkatan kualitas sumber daya manusia. Azyumardi (2009. 61) mengungkapkan bahwa peningkatan kualitas SDM melalui pendidikan merupakan salah satu cara paling efektif untuk mengentaskan kemiskinan, meskipun memerlukan waktu rerlatif Panjang. Masyarakat miskin perlu diberi "kail” yang diperoleh melalui pendidikan, dan selaras 
dengan kebijakan dalam sektor lain seperti teknologi dan industrilisasi. Bagi Azyumardi, pengentasan kemiskinan saat ini hanya sekadar jargon. Peningkatan kualitas sumber daya manusia telah dipraktekkan pada zaman Nabi Muhammad SAW. Sebagai pendidik dan Rasul, misi kependidikan Nabi Muhammad SAW adalah pertama, menanamkan akidah tahid (mengesakan Tuhan) dan memahami keseluruhan fenomena alam dan kemanusiaan sebagai suatu kesatuan yang holistik. Meningkatkan kualitas sumber daya manusia adalah dengan meningkatkan iman, ilmu, dan amal.

Kedua, menurut Azyumardi Azhra (2009. 62) bahwa Nabi Muhammad SAW membangun masyarakat sosial-politik dalam lingkup keagamaan Islam Madinah. Salah satu contohnya adalah pemanfaatan masjid selain sebagai tempat shalat juga sebagai penyelenggaraan pendidikan. Ramayulis (2011. 45) bahwa Nabi Muhammad SAW bermusyawarah tentang berbagai urusan, mendirikan shalat berjamaah, membacakan alQur'an, dan membaca ayat-ayat yang baru diturunkan. Masjid merupakan pusat pendidikan dan pengajaran. Dalam pendidikan Islam, masjid selain sebagai tempat ibadah juga menjadi tempat pengajaran dan pendidikan. Demokrasi pendidikan Islam telah diterapkan semasa hidup Nabi Muhammad SAW, yaitu dengan menekankan pentingnya berkumpul dan berdiskusi dalam sebuah ruang publik terbuka. Menurut Ramayulis (2011. 29), masjid juga menjadi tempat untuk mereka yang sudah tidak kuat atau karena miskin. Mereka juga diberikan bantuan harta dari kaum muslimin, baik kaum Muhajirin maupun Anshor yang berkecukupan. Sehingga masyarakat miskin semasa Nabi Muhammad SAW, mendapatkan kehidupan lebih baik dan harta yang cukup.

Ketiga, kebijakan Nabi Muhammad SAW membebaskan kaum non-muslim (Quraisy) setelah mengajar anak-anak muslim membaca dan menulis (Azhra, 2009. 63). Demokrasi pendidikan menekankan pentingnya menghargai sesama manusia, memandang setara setiap manusia, dan tidak membedakan antara satu dengan yang lain. Setiap manusia berhak memperoleh akses pendidikan yang sama dalam kehidupan dengan beragam suku, ras, dan agama. Dalam kehidupan beragama, sikap toleransi sangat penting untuk menjamin kedamaian dan ketentraman hidup masyarakat multikulturalisme. Sementara sikap saling menghargai satu sama lain mampu meminimalisasi tindakan rasisme dan chauvinistik. Bagi Tobroni (2018. 13) bahwa ada upaya-upaya dalam membangun sikap multikulturalisme melalui pendidikan agama di sekolah, antara lain: mengembangkan sikap multikulturalisme dalam kurikulum pendidikan, yaitu dengan trilogi kerukunan (kerukunan intern umat beragama, kerukunan antar-umat beragama, dan kerukunan antar-umat beragama dengan pemerintah); ada kajian tentang persoalan radikalisme secara adil; dan saling menghormati antar-umat beragama dan antar-budaya.

Sejalan dengan misi kependidikan Nabi Muhammad SAW bahwa untuk meningkatkan kualitas sumber daya manusia adalah dengan meningkatkan aspek intelektual, emosional, dan spiritual. Demokrasi pendidikan di Indonesia telah diatur dalam UUD No. 20 Tahun 2003 tentang Sistem Pendidikan Nasional. Inti dari demokrasi 
pendidikan adalah memberikan akses merata pada setiap warga negara; dukungan dari guru bagi peserta didik yang tinggal di daerah pedalaman dan peserta didik berkebutuhan khusus; adanya interaksi pengetahuan antara guru dan peserta didik; adanya keseimbangan antara hak dan kewajiban dalam pendidikan. jika poin-poin di atas telah dilaksanakan, maka akan tercipta demokrasi pendidikan di Indonesia, terlebih lagi dalam kondisi pandemi Covid-19. Meningkatkan aspek-aspek intelektual, spiritual dan emosional akan melahirkan manusia yang berkepribadian empatis dan solid. Chomsky sendiri memberikan sebuah solusi untuk menjadi bagian dari politik dan menjadi warga negara taat hukum. Dengan sumber daya manusia yang kompeten, matang, dan handal maka seorang individu mampu mengambil sebuah kebijakan tentang pendidikan yang memanusiakan manusia.

Keseimbangan antara iman, ilmu, dan akal mampu membentuk peserta didik menjadi pribadi yang berimana, beramal soleh, dan berdaya saing dalam dunia akademis. Kemampuan Sumber Daya Manusia tidak terlepas dari meningkatnya ekonomi masyarakat Indonesia. Persoalan kemiskinan menjadi salah satu kendala terbesar dalam demokrasi pendidikan. Upaya islam untuk mengentaskan kemiskinan adalah dengan zakat dan melalui peningkatan pendidikan bagi kelas bawah. Azhra (2009. 62) bahwa sebagai pendidik sekaligus Rasul, misi kependidikan Nabi Muhammad SAW adalah menanamkan akidah yang benar, yaitu akidah tauhid dan memahami seluruh fenomena alam serta kemanusiaan sebagai suatu kesatuan holistik. Dalam rangka meningkatkan pendidikan, keseimbangan antara emosional (EQ) dan intelektual (IQ) sangat dibutuhkan. Keseimbangan emosional, intelektual, dan spiritual merupakan satu kesatuan holistik yang mampu membentuk manusia sebagai pribadi utuh. Manusia pintar secara intelektual, yang mampu memahami keberadaan sesama manusia, dan mampu bertoleransi terhadap lingkungan sekitar.

\section{SIMPULAN}

Pendidikan di Indonesia yang telah diatur dalam UU No. 20 tahun 2003 memuat banyak sekali pedoman bagaimana menyelesaikan suatu persoalan ketidakmerataan akses pengetahuan, terutama bagi peserta didik di daerah pedalaman. Namun realitasnya pendidikan hanya merupakan sebuah kebijakan yang berganti setiap tahun. Kebijakan pendidikan tidak dibuat dalam jangka waktu panjang. Kebijakan pendidikan hanya kebijakan aksidental semata. Terkait dengan dampak yang ditimbulkan akibat perkembangan globalisasi di Era Kontemporer, pendidikan ideal adalah pendidikan yang memanusiakan manusia. Fokus pendidikan adalah berkaitan dengan kebutuhan peserta didik, yang kemudian melahirkan manusia bebas dan kreatitif.

Peserta didik yang bebas, setara, dan kreatif tidak perrnah tercapai tanpa dukungan dari guru dan pemerintah terkait. Guru yang secara aktif mampu memahami kebutuhan siswa merupakan modal awal terciptanya pendidikan yang memanusiakan, yang bukan hanya dipandang dari akumulasi nilai-nilai kuantitatif semata. Pendidikan yang 
memanusiakan manusia adalah pendidikan yang fokus pada minat dan kebutuhan siswa. Pendidikan bukan lagi mengantarkan siswa menjadi individu prestasi, mendominasi satusama lain, dan menjadi pemenang dari segala kompetisi ilmiah.

Keseimbangan peserta didik dalam IQ, EQ, dan SQ merupakan modal pendidikan membentuk manusia dengan kualitas SDM yang seimbang. Pendidikan yang seimbang akan mengantarkan pada seorang individu yang mampu membuat kebijakan politik secara adil dan merata, bukan kebijakan berdasarkan kelompok tertentu. Di satu sisi, perkembangan globalisasi mendorong manusia untuk mendominasi satu dengan manusia lainnya. Namun di sisi lain, perkembangan globalisasi pada Era Kontemporer, memunculkan berbagai gagasan untuk menghargai dan menyetarakan manusia, serta menguatkan pesan pentingnya pendidikan ideal, merata, dan memanusiakan manusia.

\section{DAFTAR PUSTAKA}

Azhra, Azyumard. 2009. Pendidikan Islam: Tradisi dan Modernalisasi di Tengah Milineum III, Jakarta: Prenada Media.

Dewey, John. 1938. Experience and Education. Kappa Delta Pi: New York.

Leonard J. Waks, 2007. Rereading Democracy and Education Today: John Dewey on Globalization, Multicultural and Democratic Education: dalam Jurnal Education and Culture Vol.23, No.1.

Lorenz Bagus, 2000. Kamus Filsafat. Jakarta: Gramedia.

Noam Chomsky, 2003. Demoracry and Education. Routledge: New York.

Philip W. Jackson, 1998. The Moral Life of Schools. Jossey-Bass Inc: New York.

Ramayulis, 2011. Sejarah Pendidikan Islam: Perubahan Konsep, Filsafat dan Metodologi Era Nabi Muhammad SAW Sampai Ulama Nusantara. Kalam Mulia: Jakarta.

Richard H. Propkin dan Avrum Stroll (ed). 1982. Philosophy Made Simple. Crown Publishing: New York.

Tampio, Nicholas, 2006, "What's the Alternative? John Dewey's Vision", dalam Learning versus the Common Core, University of Minnessota Press, Upper Midwest.

Teguh Sihono. 2011. Upaya Menuju Demokratisasi Pendidikan. Jurnal Ekonomi dan Pembangan Vol 8, No. 1.

Tobroni, dkk. 2018. Memperbincangkan Pemikiran Pendidikan Islam. Prenadamedia Grup: Jakarta. 
Karunia, Ade Miranti. 2020. "Dampak Covid-19, Menaker: Lebih dari 2 Juta Pekerja DiPHK dan Dirumahkan”. Dalam https://money.kompas.com/read/2020/04/23/174607026/dampak-Covid-19menaker-lebih-dari-2-juta-pekerja-di-phk-dan-dirumahkan. Diakses 29 Juni 2020.

Tim Komunikasi GT Nasional. (2019). "Inovasi Guru di Perbatasan Manfaatkan Radio Sebagai Media Belajar Mengajar”. Dalam https://Covid19.go.id/p/berita/inovasiguru-di-perbatasan-manfaatkan-radio-sebagai-media-belajar-mengajar. Diakses 29 Juni 2020.

NN, 2020, "Kemendikbud Terbitkan Pedoman Penyelenggaraan Belajar dari Rumah" Dalam https://www.kemdikbud.go.id, Diakses 29 Juni 2020.

Al-Qurtubu. Dalam http://quran.ksu.edu.sa/tafseer/qortobi/sura3-aya79, Diakses 29 Juni 2020. 